\title{
Theory and Practice of the Constructivism Approach in Learning in Smart Exelensia SMP in the Pandemic Era
}

\author{
M. Givi Efgivia1*, Eka Kurniasih ${ }^{2}$, Novi Utami ${ }^{3}$, Tazkiyyah H.U ${ }^{4}$ \\ 1,2,3,4 Postgraduate Educational Technology, University of Ibnu Khaldun Bogor Indonesia \\ *Corresponding author email: mgivi@uika-bogor.ac.id
}

\begin{abstract}
Constructivism learning theory is a theory that focuses on meeting learning needs or seeking their needs with the ability to find these desires or needs by being assisted by other people or the environment, so that with this theory it will provide opportunities for activeness for humans to learn to find their own competence, knowledge, or technology. and other things needed to develop itself. Constructivism learning theory argues that through knowledge and meaningful competencies will be formed based on their experiences. In constructivism, learning is represented as a constructive process in which students construct internal illustrations of knowledge, interpretations of personal experiences. Teaching science through a constructivist approach is based on learning that occurs through the active involvement of students in the construction of meaning and knowledge. Constructivist view that emphasizes discovery, experimentation, and open problems, this time doing Project based learning for the learning process with an experience.
\end{abstract}

Keywords: Constructivism, knowledge, experience

\section{INTRODUCTION}

Based on the learning objectives in the 2013 curriculum, the learning process should be able to motivate students to understand various concepts and their applications. Science and social concepts are often related to life so that the scientific content learned in class can be applied in everyday life. The actual learning practice is being able to create a pleasant atmosphere for students or what is called independent learning (Mustaghfiroh, 2020). Students can understand the concept of subject matter in the book in a fun, effortless but meaningful way. Learning should be able to direct students to become creative, independent students, and able to understand various concepts and their applications.

Education has a mandate to prioritize learning processes that are able to answer the challenges of life in the future. Education needs to penetrate into aspects of social and community life that continue to grow rapidly. Because global life with a social culture that is also developing is more coloring the development of personality aspects of today's young generation. If education is not adaptive and its importance is not realized early on, it will affect social life which is far from Indonesian social culture.

Global warming is one of the learning materials studied in class VII SMP in the even semester, where the purpose of this material learning is students are able to understand the problem of global warming that is happening on our earth, identify the factors causing and impact of global warming on humans, the natural environment and also surrounding ecosystem. Based on preliminary studies and analysis of learning at SMP SMART Ekselensia Bogor, it is known that students have difficulty understanding questions and problems that require high reasoning power, such as identifying the factors causing global warming and its various impacts on the balance of human life and the natural environment. The results of interviews with students stated that it was very difficult to solve global warming problems, as well as analyze the factors that caused environmental imbalances that had an impact on human life and the natural environment. Students are more accustomed to answering questions by memorizing the concepts of the subject matter in the book.

The learning material on global warming at SMP SMART Ekselensia Bogor has not been maximized, which is traced through daily assessments, both written and through oral questions and answers, in the last 2 years. In 2019 only about $50 \%$ of students answered questions correctly with an average IPA score of 65 and in 2020 around $64 \%$ of students answered questions correctly with an average IPA score of 68 . The percentage of students who answered questions was not optimal. The questions correctly are certainly an obstacle in achieving the successful achievement of mastery learning outcomes in accordance with the indicators that have been formulated. Students need to be involved in the learning process that can develop activity to understand the situation of environmental problems through investigation, not 
remembering, memorizing, and repeating. One of the efforts that can be done in overcoming this problem is the application of problem based learning (PBL) models and radical constructivism models.

The PBL model is a learning model that provides opportunities for students to build and discover their own knowledge concepts through a series of scientific activities such as identifying problems, investigating, hypothesizing and expressing ideas. This learning model activity confronts students with various question or task situations that require them to be responsible for solving problems, which will make students independent, creative and able to apply scientific content in everyday problems. In PBL students can practice decision making based on real-life problems. Students can also develop skills, think critically and then apply knowledge to create a project that will solve the problem presented. Learners can gain invaluable experience by doing and actively participating in the learning process. Compared to just reading the information presented in the textbook.

The choice of applying the PBL learning model based on the concept of constructivism learning will involve students in understanding reality and facts and will make students as students who are able to analyze problems or phenomena critically, logically and deeply which will ultimately improve student learning outcomes (Herr, 2014). Learning models with a constructivist approach can be a solution in answering the gap between the ideal world of education and the realistic life faced by students today. Through constructivist learning, students will be able to see and understand reality, develop thinking skills and involve feelings that motivate them to do something concrete. The central idea of constructivist theory states that the learning process is a knowledge construction process.

The choice of the constructivism model in learning about global warming, especially during a pandemic like today will provide a lot of stimulus for students to develop their knowledge through several skills into a learning experience. Students are expected to have a concern for the environment, and their creativity will also appear to play a role in caring for this nature.

The emergence of student participation in learning because it has moral and social responsibilities, will help and stimulate other students to take advantage of opportunities both in terms of technology and in nature. So that when both models are carried out, students will get the experience that becomes the learning goal.

\section{METHOD}

The research method is using the type of qualitative research. This research process is carried out by researching and analyzing references from baboon books, supporting books, websites, YouTube, and group discussions related to the theme of constructivism learning theory.

\section{RESULT AND DISCUSSION}

Constructivism is a theory about how students construct knowledge from experiences unique to each individual. Constructivist learning theory argues that people generate knowledge and form meaning based on their experiences. Constructivism as an approach to learning that emphasizes students to build their knowledge from the experience gained so that this approach allows effective learning.

Through the treatment carried out by involving students in the learning process on global warming material gradually and adjusted to conditions, it gives good results, can be accounted for. Optimization of knowledge carried out with the experience of students raises the spirit of contributing to learning outcomes and caring for the environment properly and wisely.

The learning outcomes that emerged showed that the project based learning (PBL) model and the constructive model gave the students enthusiasm in understanding the lesson. It is proven by a significant increase in student learning outcomes, where $75 \%$ of students get a score of 78 on global warming material. Shows that students' understanding of this material which is taught by involving students in the learning process, especially because of the demands during the pandemic, gets good and significant results.

Constructivism theory is a popular theory for the world of education. Constructivism means constructive. In the context of the philosophy of education, constructivism is an attempt to build a modern cultured life structure. Based on the explanation above, that constructivism is a theory that is constructive, builds in terms of ability, understanding, in the learning process. Because by having a constructive nature, it can be expected that the activeness of students will increase their intelligence and abilities.

Shymansky said constructivism is an activity in which students build their own knowledge, seek meaning from what they learn, and is a process of completing new concepts and ideas with their existing framework of thinking. Constructivism is an effort to activate students by providing the widest possible space to understand what they have learned by applying the concepts they know and then putting them into practice in their daily lives. 
It can be concluded that constructivism is a theory that gives students the breadth of thinking and gives students the opportunity to practice the theory they already know in their lives. No theory is perfect but complementary to one another as well as constructivism. There are several advantages of constructivism theory, including:

$\checkmark$ Learning based on constructivism provides opportunities for students to express ideas explicitly using the students' own language, share ideas with their friends, and encourage their friends to explain their ideas.

$\checkmark \quad$ Learning based on constructivism provides experiences related to the ideas that students already have or the design of activities adapted to the initial ideas of students in order to expand their knowledge of phenomena and have the opportunity to assemble phenomena, so that students are encouraged to distinguish and integrate ideas about phenomena challenging. Constructivism learning gives students the opportunity to think about their experiences. This can encourage students to think creatively, imaginatively, encourage reflection on models and theories, introduce ideas at the right time.

$\checkmark$ Learning based on constructivism provides opportunities for students to try new ideas so that they are encouraged to gain confidence by using various contexts, both known and new and ultimately motivate to use various learning strategies. Students who learn constructivism are given the opportunity to build their own understanding of something. This makes them more confident in themselves and brave to face and solve problems in new situations.

$\checkmark$ Constructivism learning provides a conducive learning environment that supports students in expressing ideas, listening to each other, and avoiding the impression that there is always one right answer.

$\checkmark \quad$ Students who have social skills can cooperate with other friends in dealing with problems. These social skills are obtained when students interact with friends, teachers, and their environment.

The constructivism learning model has several obstacles in its application. There are several obstacles that may arise in the application of learning theory with a constructivist approach, namely:

$\checkmark \quad$ The teacher finds it difficult to provide concrete and realistic examples in the learning process. In this case, the teacher must have high creativity in conveying the material.

$\checkmark$ Teachers do not want to change in using the learning model. Teachers feel comfortable with the traditional learning model, namely the lecture model. The teacher's view of students is likened to students as an empty vessel that needs to be filled by the knowledge possessed by the teacher. Teachers feel that using the traditional model alone can get a high score, so there is no need to use other learning models.

$\checkmark \quad$ Teachers think that learning constructivism requires more time. The constructivist learning process wants to make students active, this is sometimes also constrained by the cognitive abilities of students. The burden of teaching teachers is too much.

$\checkmark \quad$ There is no sufficient laboratory equipment for a large number of students. Most schools are still limited in providing facilities to support constructivism learning. Facilities and infrastructure do not support constructivism model learning.

$\checkmark$ Mastery of the material by the teacher is inadequate.

The constructivist view directs that a person constructs part of his knowledge and experience using mental structures and beliefs that are used to interpret objects and events. If this is used as an assumption in the evaluation, then the evaluation must be individual and adapted to the learning context. This is because the learning process starts from the initial knowledge of students who are not the same and learning activities refer to projects carried out by students according to their choices.

\section{CONCLUSION}

The application of the PBL model with the radical constructivism method has an effect on student learning outcomes. The findings consistently show that cognitive learning outcomes can be achieved if students are involved in various learning activities and actions, by actively constructing their understanding through the reality and facts around them. When knowledge is actively built by students, the learning process that is formed is student center and built for students so that comfort and love arise, the curriculum used is also studentoriented, and the teacher is only a facilitator, so the results of developing knowledge become an enjoyable experience. be the target of learning.

\section{REFERENCES}

[1]. Setiyowati, A., Salsabila, U. H., Zulaika, R., Arista, V. A., \& Santoso, Y. W. (2020). PERAN TEKNOLOGI PENDIDIKAN DALAM PENGGUNAAN E-LEARNING SEBAGAI PLATFORM PEMBELAJARAN DIMASA PANDEMI COVID-19. EDURELIGIA: Jurnal Pendidikan Agama Islam, 4(2), 196-206.

[2]. Suparlan, S. (2019). Teori Konstruktivisme dalam Pembelajaran. Islamika, 1(2), 79-88. 
https://doi.org/10.36088/islamika.v1i2.208

[3]. Ulhaq*, R., Huda, I., \& Rahmatan, H. (2020). Pengaruh Model Pembelajaran Problem Based Learning Dengan Modul Kontruktivisme Radikal Terhadap Hasil Belajar Peserta Didik. Jurnal IPA \& Pembelajaran IPA, 4(2), 244-252. https://doi.org/10.24815/jipi.v4i2.17874

[4]. Yensy, N. A. (2020). Efektifitas
Pembelajaran Statistika Matematika melalui Media Whatsapp Group Ditinjau dari Hasil Belajar Mahasiswa (Masa Pandemik Covid 19). Jurnal Pendidikan Matematika Raflesia, 5(2), 65-74.

[5]. (Setiyowati et al., 2020)

[6]. (Suparlan, 2019)

[7]. (Yensy, 2020)

[8]. (Ulhaq* et al., 2020) 